\title{
ИЗУЧЕНИЕ КОМБИНИРОВАННОГО ДЕЙСТВИЯ ГЕФИТИНИБА И ИНГИБИТОРОВ IX И ХІІ ИЗОФОРМ КАРБОАНГИДРАЗЫ ЧЕЛОВЕКА В ПРОТИВОРАКОВОЙ ОБЛАСТИ
}

\section{Т.В. Шаронова' ${ }^{1}$ С.А. Калинин', А.С. Бунев², М.Ю. Красавин'}

${ }^{1}$ Институт Химии, г. Санкт-Петербургский государственный университет, 198504 , Россия, Санкт-Петербург, Университетский пр-т, д. 26.

${ }^{2}$ Центр медицинской химии, Тольяттинский государственный университет, 445020, Россия, г. Тольятти, Самарская область, ул. Белорусская, д. 14.

DOI: 10.19163/MedChemRussia2021-2021-106

E-mail: tat.sharonowa2016@yandex.ru

Устойчивость раковых клеток к терапии представляет собой основную проблему при лечении рака. Раковые клетки развивают резистентность почти ко всем химиотерапевтическим агентам [1]. Такая адаптация может быть обусловлена мутациями, либо повышенной экспрессией определенных белков. В частности, гиперэкспрессия ассоциированных с опухолью IX и XII изоформ человеческой карбоангидразы (КАЧ IX и XII) отвечает за регуляцию внутри- и внеклеточного $\mathrm{pH}$, а также способствует адаптации к гипоксии и пролиферации раковых клеток [2].

Одним из путей преодоления лекарственной устойчивости является стратегия комбинирования лекарственных средств, которая может снизить частоту возникновения резистентности [3]. Поэтому комбинированная терапия с использованием ингибиторов КАЧ IX и XII для подавления наиболее устойчивых фенотипов раковых клеток является перспективным подходом в онкологии [4].

Ранее нами была синтезирована серия наномолярных ингибиторов КАЧ IX и XII [5], однако эффективность этих молекул в качестве индивидуальных агентов против раковых клеток оказалась недостаточна. В настоящей работе мы исследовали комбинацию этих ингибиторов КАЧ IX и XII с Гефитинибом, и их совместное действие привело к резкому увеличению цитотоксичности против клеточных культур рака легкого, чувствительных к Гефитинибу.

\section{Литература}

[1] S. Kobayashi, T.J. Boggon, et al., N Engl J Med. 2005, 352; 8, 786-792;

[2] C.T. Supuran, J. Enzyme Inhib. Med. Chem. 2018, 33; 1, 485-495;

[3] S.T. Pan, et al., Clin. Exp. Pharmacol. Physiol. 2016, 43; 8, 723-737;

[4] L. Dubois, et al., Radiother Oncol. 2011, 99; 3, 424-431;

[5] M. Krasavin, A. Shetnev, T. Sharonova, S. Baykov, et al., Eur. J. Med. Chem. 2019, 164, 92-105.

$$
-106-
$$

